\title{
Morpho-anatomical effects of sodium azide and nitrous acid on Citrullus lanatus (Thunb.) Matsum. \& Nakai (Cucurbitaceae) and Moringa oleifera Lam. (Moringaceae)
}

\author{
AbdulRahaman, A.A. ${ }^{1,4}$, Afolabi, A.A. ${ }^{1}$, Zhigila, D.A. ${ }^{2}$, Oladele, F.A. ${ }^{1}$ and Al Sahli, A.A. ${ }^{3}$
}

Received: 14.05.2017; accepted: 2.04.2018

\begin{abstract}
Morpho-anatomical effects of sodium azide and nitrous acid on Citrullus lanatus (Thunb.) Matsum. \& Nakai (Cucurbitaceae) and Moringa oleifera Lam. (Moringaceae) ). Chemical mutagens (e.g. sodium azide and nitrous acid) are important tools in crop improvements because they produce resistance against pathogens in crops to improve their yield and quality traits. This study investigates the morphological and anatomical effects of sodium azide and nitrous acid on Citrullus lanatus and Moringa olefeira at various concentrations ( $1 \mathrm{mM}, 2 \mathrm{mM}, 3 \mathrm{mM}$ and $4 \mathrm{mM})$ for 4 hours, and planted in plastic pots for 12 weeks observations. Results showed that sodium azide and nitrous acid have differential influenced on morphological features (stem height, leaf number and root length) in C. lanatus and M. olefeira respectively. Anatomical features (stomatal density, index and size) are more influenced by the sodium azide-treated plants in both plants than in the nitrous acid-treated plants. Both mutagens are more effective in the two plants than the control.
\end{abstract}

Keywords: chemical mutagens, leaf, leaf anatomy, morphology, root, stem

RESUMO - (Efeitos morfo-anatômicos da azida sódica e ácido nitroso em Citrullus lanatus (Thunb.) Matsum. \& Nakai (Cucurbitaceae) e Moringa oleifera Lam. (Moringaceae)). Os agentes mutagénicos químicos (por exemplo, azida de sódio e ácido nitroso) são ferramentas importantes na melhoria das culturas porque produzem resistência contra patogénios nas culturas para melhorar as suas características de rendimento e qualidade. Este estudo investiga os efeitos morfológicos e anatômicos da azida sódica e do ácido nitroso em Citrullus lanatus e Moringa olefeira em várias concentrações (1 mM, $2 \mathrm{mM}, 3 \mathrm{mM} \mathrm{e} 4 \mathrm{mM}$ ) por 4 horas, e plantados em vasos plásticos para observações de 12 semanas. Os resultados mostraram que a azida sódica e o ácido nitroso têm influência diferencial nas características morfológicas (altura do caule, número de folhas e comprimento da raiz) em C. lanatus e M. olefeira, respectivamente. Características anatômicas (densidade, índice e tamanho dos estômatos) são mais influenciadas pelas plantas tratadas com azida de sódio em ambas as plantas do que nas plantas tratadas com ácido nitroso. Ambos os mutagênicos são mais eficazes nas duas plantas que o controle.

Palavras-chave: anatomia foliar, caule, folha, morfologia, mutagenes químicos, raiz

\section{Introduction}

Mutation methodology has been used to produce many cultivars with improved economic value and study of genetics and plant developmental phenomena (Van et al. 1990, Bertagne-Sagnard \& Chupeau 1996). It has been demonstrated that genetic variability for several desired characters can be induced successfully through mutations and its practical value in plant improvement programs has been well established. The main advantage of mutation breeding is the possibility of improving one or two characters without changing the rest of the genotype. Induced mutations have great potentials and serve as a complimentary approach in genetic improvement of crops (Mahandjiev et al. 2001). Induced mutations have been used to improve major food crops like wheat, rice, barley, cotton, peanut and cowpea, which are seed propagated plants. It is known that various chemicals have positive or negative effects on living organisms. These effects can occur both spontaneously and artificially following induction by mutagens. These chemomutagens induce

1. Universidade de Ilorin, Departamento de Botânica, Laboratório Aplicado de Anatomia Vegetal, 240222 Ilorin West, Nigeria, África

2. Universidade Estadual de Gombe, Departamento de Ciências Biológicas, Nigéria, África

3. Universidade King Saud, Departamento de Botânica e Microbiologia, 11362 Riyadh, Arábia Saudita

4. Corresponding author: abdulrahamanaa@unilorin.edu.ng 
a broad variety of morphological and yield structure parameters in comparison to normal plants. Many researchers compared the mutagenic efficiencies of different mutagens on different crops and their results seem to be entirely specific for particular species and even varieties. The mutants, so produced facilitate the isolation, identification and cloning of genes used in designing crops with improved yield and quality traits (Ahloowalia \& Maluszynski 2001).

Among the popular chemomutagens are sodium azide and nitrous acid. Sodium azide $\left(\mathrm{NaN}_{3}\right)$ affects plant physiology and decrease cyanide resistant respiration in tobacco callus (Wen \& Liang 1995). It is known to be highly mutagenic in several organisms, including plants and animals (Raicu and Mixich 1992, Grant \& Salamone 1994, Al-Qurainy, 2009, Gruszka et al. 2012, AbdulRahaman et al. 2013) and its mutagenic potential has been reported in several screening assays. Nitrous acid, on the other hand, is a potent chemical mutagen, exerts its effect by the deamination of the amino groups of the adenine, cytosine and guanine residues of the nucleic acid causing chemical alterations as well as cross-links of undefined structures deletions (Burnotte \& Verly 1971, Miller 1972). Although, nitrous acid mutagenesis is used for genetic improvement of virus, fungi and bacteria for multiple biotechnological purposes, its exploitation in plant genetic improvement has been lacking. Since nitrous acid quite unstable, the mutagenic treatments nitrous acid need to be quick e.g. not longer than a few minutes, which makes the treatment of dry seeds ineffective. Although genetic engineering has made a significant contribution to strain improvement, random mutagenesis is still a cost-effective procedure for reliable short-term strain development and its frequently the method of choice (Mishra et al. 2014).

Citrullus lanatus (Thunb.) Matsum. \& Nakai is a plant species in the family Cucurbitaceae, a vine-like (scrambler and trailer) flowering plant originally from West Africa. It is cultivated for its fruit. It is a large, sprawling annual plant with coarse, hairy pinnatelylobed leaves and white to yellow flowers. It is grown for its edible fruit, also known as a watermelon, which is a special kind of berry botanically called a pepo. The fruit has a smooth, hard rind, usually green with dark green stripes or yellow spots, and a juicy, sweet interior flesh, usually deep red to pink, but sometimes orange, yellow, or white, with many seeds. The effects of the two mutagens were studied with $C$. lanatus (watermelon). C. lanatus is an important horticultural crop, mostly known for its sweet and juicy fruit. In Africa, watermelon accounted for $5.4 \%$ of the harvested area devoted to vegetable production in 2008, and this contributed to the world watermelon production with $4.6 \%$ of $99,194,223$ tonnes (FAOSTAT 2008).

Moringa oleifera Lam. is the most widely cultivated species of the genus Moringa, which is the only genus in the family Moringaceae. It is native to the southern foothills of the Hamalayas in northwestern India, and widely cultivated in tropical and subtropical areas where its young seed pods and leaves are used as vegetables. It can also be used for water purification and hand washing, and is sometimes used in herbal medicine (Leone et al. 2015). Moringa oleifera is a fast-growing, deciduous

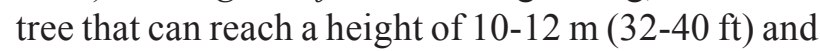
trunk diameter of $45 \mathrm{~cm}(1.5 \mathrm{ft})$ (Parotta, 1993). The bark has a whitish-grey colour and is surrounded by thick cork. Young shoots have purplish or greenishwhite, hairy bark. The tree has an open crown of drooping, fragile branches and the leaves build up a feathery foliage of tripinnate leaves.

The flowers are fragrant and asexual, surrounded by five unequal, thinly veined, yellowish-white petals. The flowers are about 1.0-1.5 cm (1/2") long and $2.0 \mathrm{~cm}(3 / 4$ ") broad. They grow on slender, hairy stalks in spreading or drooping flower clusters which have a length of $10-25 \mathrm{~cm}$. The fruit is a hanging, threesided brown capsule of 20-45 cm size, which holds dark brown, globular seeds with a diameter around $1 \mathrm{~cm}$. The seeds have three whitish papery wings and are dispersed by wind and water. In cultivation, it is often cut back annually to 1-2 m (3-6 ft) and allowed to regrow so the pods and leaves remain within arm's reach (Parotta, 1993).

This work elucidated the mutagenic effects sodium azide and nitrous acid on morphology and anatomy of $C$. lanatus and $M$. oleifera.

\section{Material and methods}

Acquisition, treatment and planting of seeds - Seeds of $C$. lanatus and $M$. oleifera seeds were collected from the Lower Niger Basin Development Authority Ilorin, and the University of Ilorin Moringa oleifera Plantation Farm, Nigeria respectively. The seeds were then added separately to the solutions of mutagens for 4 hours. The solutions were periodically agitated to ensure that they evenly take up the chemical mutagens. 
The control seeds were treated with $0.1 \mathrm{M}$ phosphate buffer. Treated and control seeds were planted in the pots for eight weeks. Each treatment was replicated three times using completely randomized design (CRD).

Morphological studies - Data were collected on the following growth parameters: germination percentage, seedling survival, seedling height, number of leaves per seedling, number of leaves per plant and root length. The data were collected every two weeks for the seedling height and number of leaf per seedling while the values for root length were collected after the experiment.

Leaf epidermal anatomy - Prepared slides of macerated cuticles from the leaves of the species were observed using 35 fields of view at $\times 40$ objectives as quadrats. The trichome occurrence, distribution and type were counted and noted. The number of subsidiary cells per stomata was noted and recorded to determine the frequency of the different stomatal complex types present in each specimen. The frequency of each complex type is expressed as percentage occurrence of such complex types based on all occurrences (Obiremi \& Oladele 2001). The terminologies for naming stomatal complex types followed those of Dilcher (1974).

The stomatal index was determined using this formula:

$$
S I=\frac{S}{E+S} \times 100
$$

Where $\mathrm{S}=$ number of stomatal per square millimeter, $\mathrm{E}=$ number of ordinary epidermal cell per square millimeter.

The stomatal density was determined as number of stomata per square millimeter.

The mean stomatal size or area was determined using this formula:

$$
l \times b \times k
$$

Where $\mathrm{L}=$ length, $\mathrm{B}=$ breadth and $\mathrm{K}=$ Franco's constant $=0.79$ (Franco 1939).

That is stomatal area is a product of the length and breadth of guard cells multiply by Franco's constant. The size of epidermal cell could also be determined as a product of the length and breadth multiply by 0.79 .

\section{Results}

Germination of seeds - Germination percentage which is an estimate of the viability of a population of seeds is $100 \%$ in both plants and each of the single seeds planted in pots survived throughout the experimental period making the seedling survival rate $100 \%$.

Morphological parameters Citrullus lanatus - The morphological data collected for seedling height, number of leaves per seedling and the root length of $C$. lanatus were shown in table 1 below. The morphological data obtained for seedling height, number of leaves per seedling and the root length. At week 8 , the longest stem $(64.80 \pm 1.77 \mathrm{~cm}$ and $64.33 \pm 5.59 \mathrm{~cm})$ was observed in $4 \mathrm{mM} \mathrm{NaN}_{3}$ treated and control plants respectively, while the shortest stem $(48.43 \pm 4.87 \mathrm{~cm})$ was in $2 \mathrm{mM} \mathrm{HNO}_{2}$ treated plants. Longer root $(16.27 \pm 2.04 \mathrm{~cm}$ and $16.00 \pm 1.40 \mathrm{~cm}$ ) was observed in $2 \mathrm{mM} \mathrm{HO}_{2}$ and $4 \mathrm{mM} \mathrm{HNO}_{2}$-treated plants respectively, and shortest route $(13.80 \pm 2.81 \mathrm{~cm}$ and $13.03 \pm 0.49 \mathrm{~cm})$ was in control and $1 \mathrm{mM} \mathrm{NaN}$-treated plants respectively. There are many leaves $(38.00 \pm 5.57)$ on the plants treated with $2 \mathrm{mM} \mathrm{NaN}_{3}$ and a small number of leaves $(26.33 \pm 3.06)$ is in $2 \mathrm{mM} \mathrm{HNO}_{2}$-treated plants.

At $2 \mathrm{WAP}$ and $8 \mathrm{WAP}$, there is no significant difference between the control, treatments $(1 \mathrm{mM}$ $\left.\mathrm{NaN}_{3}, 2 \mathrm{mM} \mathrm{NaN}_{3}, \mathrm{NaN}_{3}\right)$ and $\left(1 \mathrm{mM} \mathrm{HNO}_{2}, 2 \mathrm{mM}\right.$ $\mathrm{HNO}_{2}, 4 \mathrm{mM} \mathrm{HNO}$ ) in seedling height. At 4WAP, there is a significant difference between control, $1 \mathrm{mM}$ $\mathrm{NaN}_{3}, 1 \mathrm{mM} \mathrm{HNO}, 2 \mathrm{mM} \mathrm{HNO}$ and $4 \mathrm{mM} \mathrm{HNO}_{2}$ whereas there is no significant difference between control, $2 \mathrm{mM} \mathrm{NaN}_{3}$ and $4 \mathrm{mM} \mathrm{NaN}_{3}$. At 6WAP, there is a significant difference between the control, $4 \mathrm{mM}$ $\mathrm{NaN}_{3}$ and $1 \mathrm{mM} \mathrm{NaN}_{3}$ whereas there is no significant different between the control, $1 \mathrm{mM} \mathrm{NaN}_{3}, 2 \mathrm{mM}$ $\mathrm{NaN}_{3}, 2 \mathrm{mM} \mathrm{HNO}_{2}$ and $4 \mathrm{mM} \mathrm{HNO}_{2}$ (table 2).

Morphological studies of Moringa oleifera - After 9WAP, the highest seedlings $(64.60 \pm 3.87 \mathrm{~cm})$ were in $2 \mathrm{mMH} \mathrm{NO}_{2}$-treated plants while the shortest $(55.43 \pm 4.14 \mathrm{~cm})$ were in $4 \mathrm{mM} \mathrm{NaN}_{3}$ treated plants. More leaves $(176.00 \pm 6.08)$ were in $1 \mathrm{mMH} \mathrm{NO}_{2}$-treated plants and less number of leaves $(141.00 \pm 6.56)$ were in $1 \mathrm{mM} \mathrm{NaN}_{3}$-treated plants. Longer roots $(15.97 \pm 1.66 \mathrm{~cm}$ and $15.97 \pm 2.08 \mathrm{~cm})$ were in observed in $1 \mathrm{mM} \mathrm{HNO}_{2}$ and $2 \mathrm{mM} \mathrm{HNO}_{2}-$ treated plants respectively, while $4 \mathrm{mMHNO}_{2}$-treated and control plants produced seedlings with the shortest plants with $13.27 \pm 0.35 \mathrm{~cm}$ and $13.97 \pm 2.85 \mathrm{~cm}$ respectively (table 3 ).

For seedling height of $M$. oleifera, at $3 \mathrm{WAP}$, there is no significant difference between the control and the treatments $\left(1 \mathrm{mM} \mathrm{NaN}_{3}, 2 \mathrm{mM} \mathrm{NaN}_{3}, \mathrm{NaN}_{3}\right)$ and $\left(1 \mathrm{mM} \mathrm{HNO}_{2}, 2 \mathrm{mM} \mathrm{HNO}_{2}, 4 \mathrm{mM} \mathrm{HNO}_{2}\right.$ ). The same 


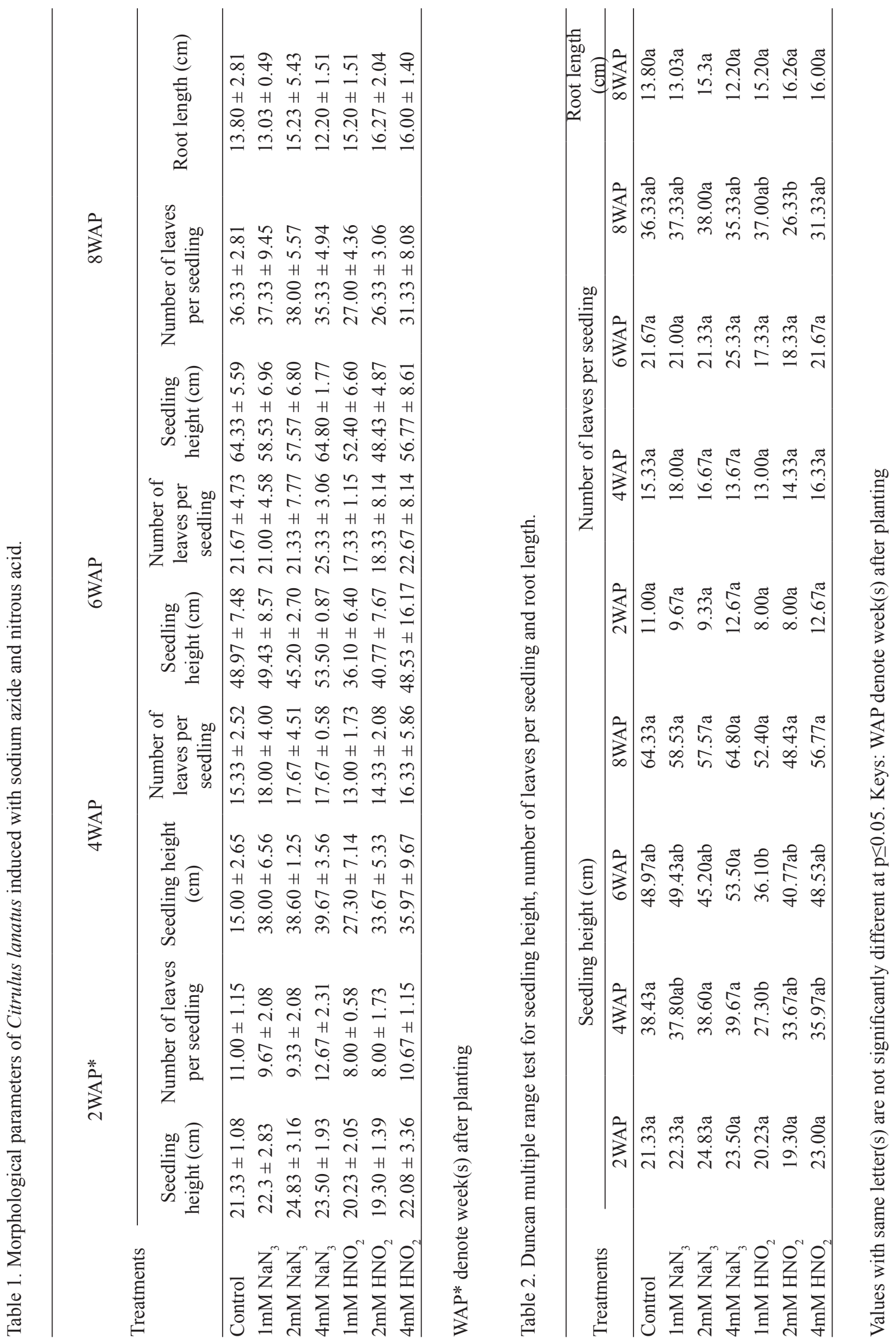


thing applies to the 5WAP, 7WAP and the 9WAP. At $3 \mathrm{WAP}$, there is a significant difference between the control and treatments $\left(1 \mathrm{mM} \mathrm{NaN}, 2 \mathrm{mM} \mathrm{NaN}_{3}\right.$, $\mathrm{NaN}_{3}, 1 \mathrm{mM} \mathrm{HNO}_{2}, 2 \mathrm{mM} \mathrm{HNO}_{2}$, and $4 \mathrm{mM} \mathrm{HNO}_{2}$ ). At $5 \mathrm{WAP}$, there is a significant difference between the control and $2 \mathrm{mM} \mathrm{NaN}_{3}, 4 \mathrm{mM} \mathrm{NaN}_{3}, 1 \mathrm{mMHON}_{2}$, $2 \mathrm{mM} \mathrm{HNO}_{2}$ and $4 \mathrm{mM} \mathrm{HNO}_{2}$ whereas there is no significant difference between the control and $1 \mathrm{mM}$ $\mathrm{NaN}_{3}$. At 7WAP, there is no significant difference between the control, $1 \mathrm{mM} \mathrm{NaN}_{3}$ and $2 \mathrm{mM} \mathrm{HNO}_{2}$ whereas there is a significant difference between the control and $2 \mathrm{mM} \mathrm{NaN}_{3}, 4 \mathrm{mM} \mathrm{NaN}, 1 \mathrm{HNO}_{2}$ and $4 \mathrm{mM} \mathrm{HNO}_{2}$. At $9 \mathrm{WAP}$, there is no significant difference between the control and $1 \mathrm{mM} \mathrm{NaN}_{3}, 2 \mathrm{mM}$ $\mathrm{NaN}_{3}$ and $4 \mathrm{mM} \mathrm{NaN}_{3}$ whereas there is a significant difference between the control and $1 \mathrm{mM} \mathrm{HNO}_{2}$, $2 \mathrm{mM} \mathrm{HNO}_{2}$ and $4 \mathrm{mM} \mathrm{HNO}_{2}$ for the number of leaves per seedling of $M$. oleifera. At 9WAP, there is no significant difference between the control and the treatments $\left(1 \mathrm{mM} \mathrm{NaN}_{3}, 2 \mathrm{mM} \mathrm{NaN}_{3}, \mathrm{NaN}_{3}, 1 \mathrm{mM}\right.$ $\mathrm{HNO}_{2}, 2 \mathrm{mM} \mathrm{HNO}_{2}$, and $4 \mathrm{mM} \mathrm{HNO}_{2}$ ) for the root length of $M$. oleifera (table 4).

Leaf anatomy Citrullus lanatus - Leaves are amphistomatic in nature, i.e. leaves with presence of stomata on both surfaces. Three stomatal complex types, namely anisocytic, tetracytic and anomocytic. Higher percentages of these complex types, stomatal index, higher stomatal density and larger stomata are observed in mutagenic-treated plants than in the control plants (figura 1). There is also the presence of multicellular trichomes on both the abaxial and adaxial surfaces of the leaf (figura 2, table 3). There was a significant difference in the stomatal size between the control and the treatments on the abaxial surface. The size of the stomata for the control of the abaxial surface is smaller than that of the treatments. The situation applies to the adaxial surface, but with an exception in the leaves treated with the $2 \mathrm{mM} \mathrm{HNO}_{2}$ where stomatal size is smaller than that of the control (table 3 ). The anticlinal walls are straight and epidermal cell shape is polygonal for both the treatments and the control. There are no visible effects of the mutagens on the epidermal cells of $C$. lanatus. The effects of mutagens ( $4 \mathrm{mM} \mathrm{NaN}_{3}, 1 \mathrm{mM} \mathrm{HNO}_{2}$ and $2 \mathrm{mM} \mathrm{HNO}_{2}$ ) on the trichomes distribution on the adaxial surface are not significantly different from each other. Also the effects of $1 \mathrm{mM} \mathrm{NaN}_{3}$ and $2 \mathrm{mM} \mathrm{NaN}_{3}$ on the adaxial surface are not significantly different from the effect of the control. The effects of treatments $4 \mathrm{mM} \mathrm{HNO}_{2}$ on adaxial surface is significantly different from the rest 

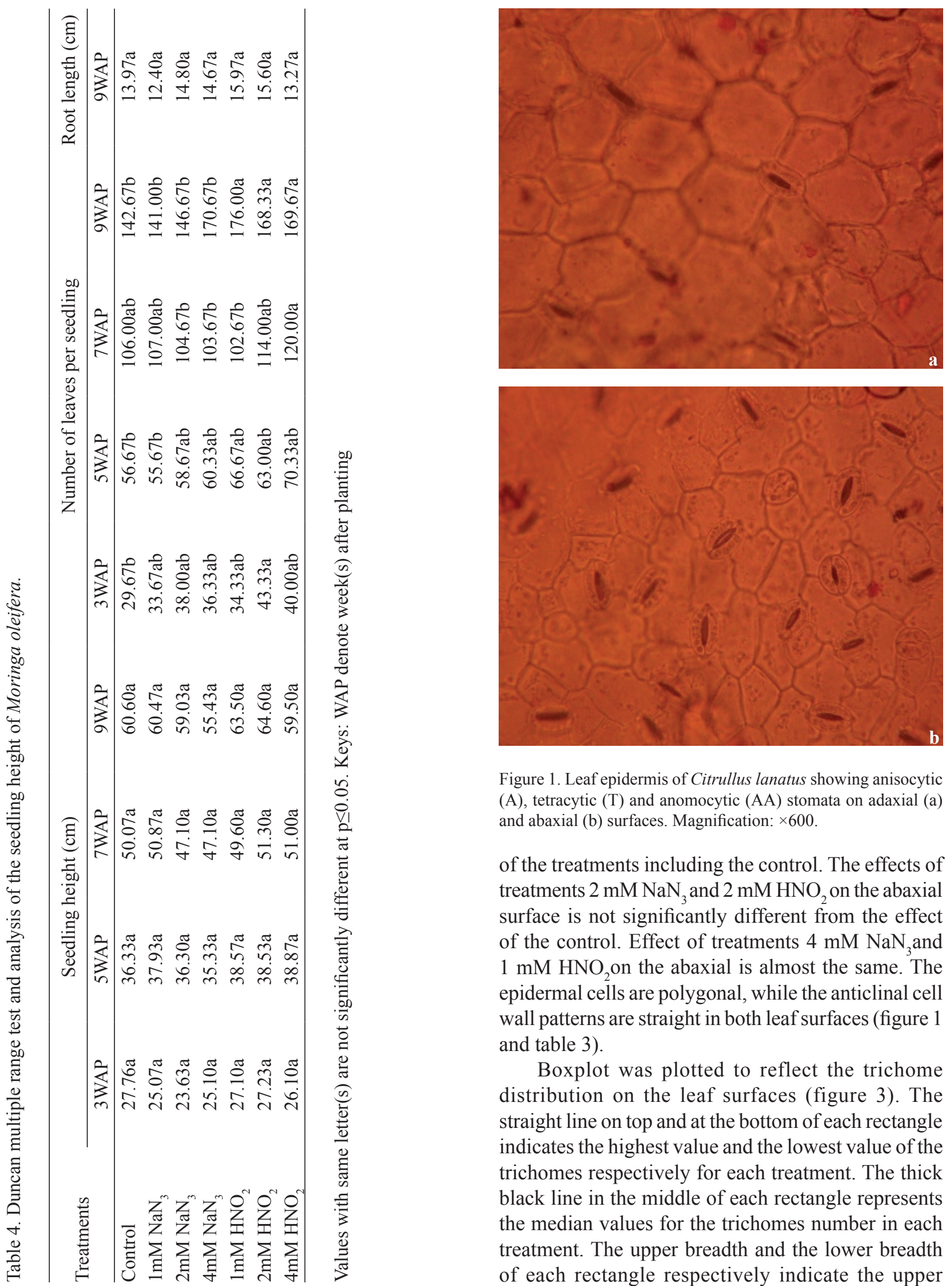

Figure 1. Leaf epidermis of Citrullus lanatus showing anisocytic (A), tetracytic (T) and anomocytic (AA) stomata on adaxial (a) and abaxial (b) surfaces. Magnification: $\times 600$.

of the treatments including the control. The effects of treatments $2 \mathrm{mM} \mathrm{NaN}_{3}$ and $2 \mathrm{mM} \mathrm{HNO}_{2}$ on the abaxial surface is not significantly different from the effect of the control. Effect of treatments $4 \mathrm{mM} \mathrm{NaN}_{3}$ and $1 \mathrm{mM} \mathrm{HNO}$ on the abaxial is almost the same. The epidermal cells are polygonal, while the anticlinal cell wall patterns are straight in both leaf surfaces (figure 1 and table 3).

Boxplot was plotted to reflect the trichome distribution on the leaf surfaces (figure 3). The straight line on top and at the bottom of each rectangle indicates the highest value and the lowest value of the trichomes respectively for each treatment. The thick black line in the middle of each rectangle represents the median values for the trichomes number in each treatment. The upper breadth and the lower breadth of each rectangle respectively indicate the upper 

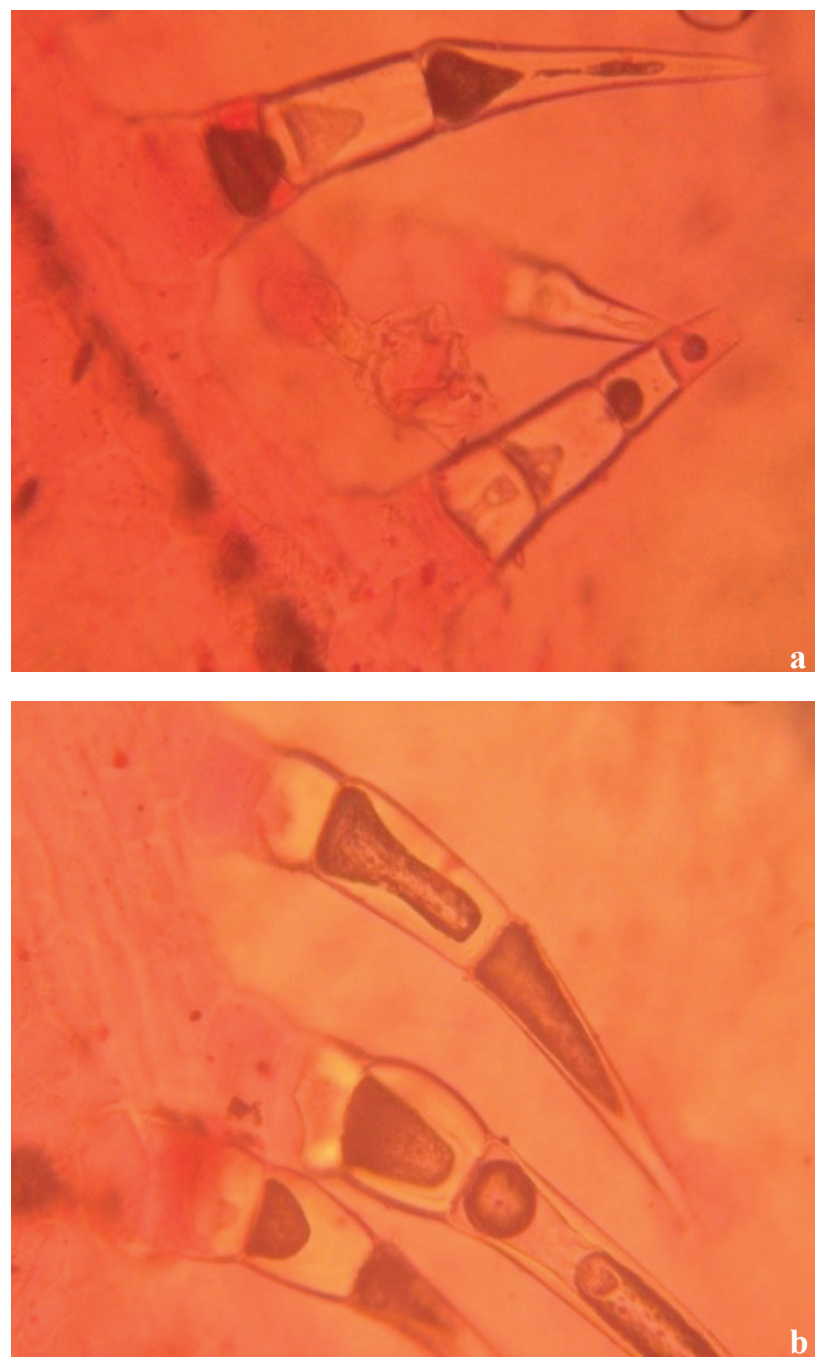

Figure 2. Multicellular trichomes on the Citrulus lanatus leaf adaxial (a) and abaxial (b) surfaces. Magnification: $\times 600$.

quartile values and lower quartile values of each of the treatment of $C$. lanatus.

Leaf anatomy of Moringa oleifera - Moringa oleifera is a hypostomatic plant (having stomata only on the abaxial surface of the leaf). The stomata types present are the anisocytic, tetracytic and anomocytic. The stomatal frequency measured in percentage indicates which of the stomatal type occur mostly on the leaf surface. The density shows the total number of the stomatal type present on the leaf surface while the stomatal size revealed the dimensional values of the stomata for each of the treatments. The stomatal size for each of the treatments in the figure below indicates that the stomatal size of the control is larger than that of $1 \mathrm{mM} \mathrm{NaN}_{3}$ and $4 \mathrm{mM} \mathrm{NaN}_{3}$ but smaller than the size of the rest of the treatments. Moringa oleifera possesses unicellular trichomes, epidermal cells are polygonal and anticlinal cell wall patterns are undulate
Box Plot Showing Leaf Surfaces with Trichomes in Watermelon

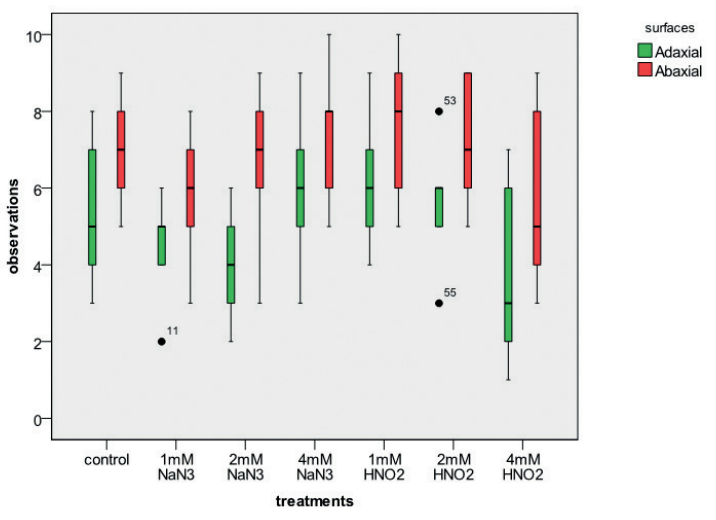

Figure 3: Trichome distribution on the leaf surfaces of Citrulus lanatus.

on both the abaxial and adaxial leaf surfaces of both the control and the treatments (figure 5, table 6).

\section{Discussion}

Sodium azide and nitrous acid treated seeds of C. lanatus germinated earlier than that of the control while both the treated and control seeds of $M$. oleifera germinated on the same day. This shows that the mutagenic potency of both the sodium azide and nitrous acid activated the RNA in the seeds of $C$. lanatus by degrading the protein present in the seeds, thereby facilitating the germination of the seeds while this was not so for the M. oleifera. The mutagenic effects of both mutagenic agents on the morphology of the studied species were not uniform. After the morphological data collected were analyzed at $\mathrm{p} \leq 0.05$, there were significant difference in the morphological characters between the treatments and the control. Also, there was no reduction in percentage germination and seedling survival, whereas sodium azide increases the seedling height and nitrous acid reduced the height of the seedling. There was no significant difference in the number of leaves per seedling and root length. The results obtained corroborate the mutagenic effect of nitrous acid on the morphological effect of sodium azide on tomato as reported by Adamu and Aliyu (2007) while the effect of the sodium azide negates their claim.

Although the potency of the two mutagens appeared not to be optimum because of the concentrations at which they were applied. In view of this, certain inferences could be drawn on the similarities and differences on the effectiveness of both mutagens at such low concentration. 

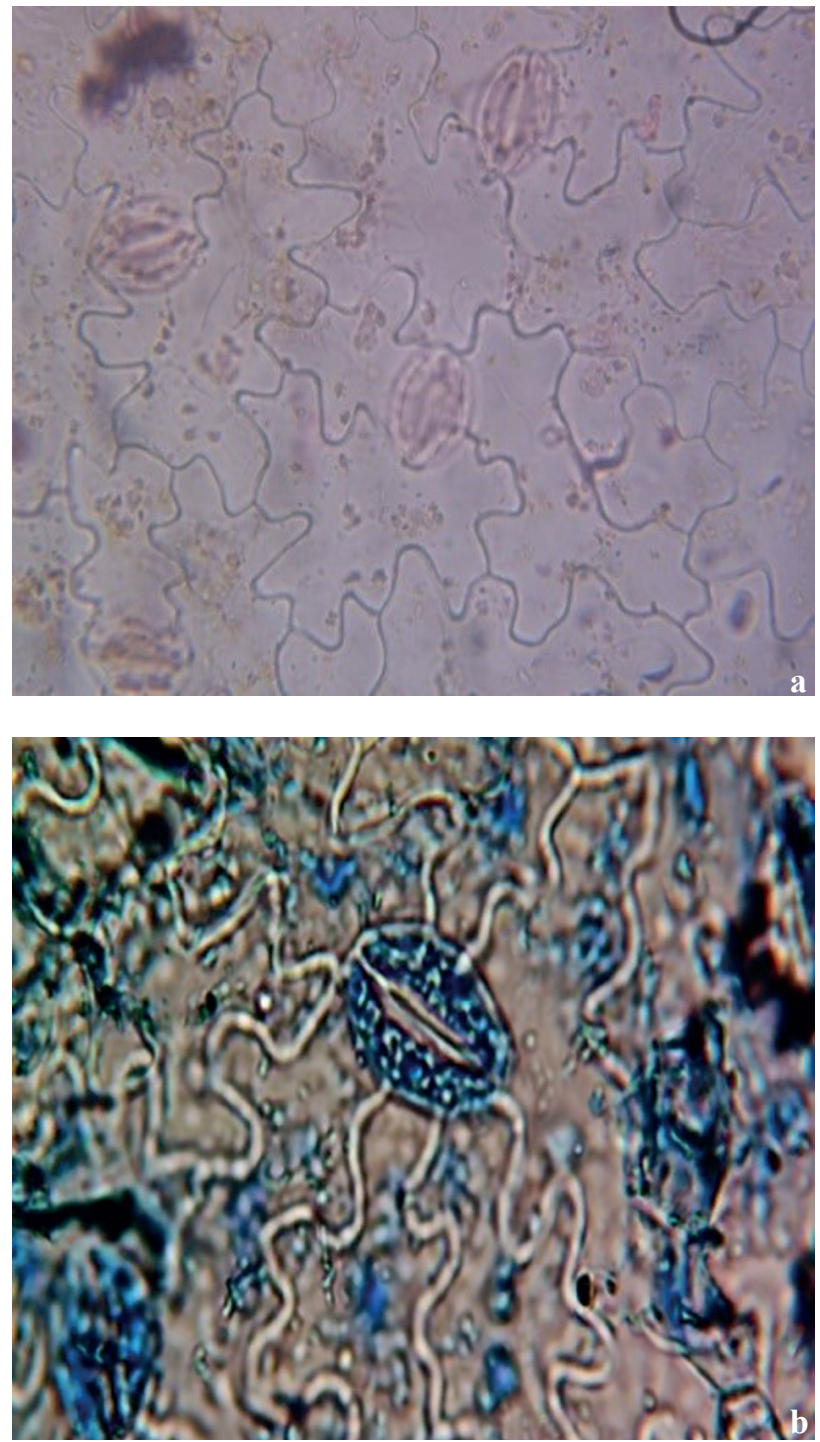

Figure 4. Abaxial leaf epidermis of Moringa oleifera showing anisocytic (A), tetracytic (T) and anomocytic (AA) stomata. Magnification: $\times 600$.

The data recorded on seed germination at $3 \mathrm{WAP}$ for $M$. oleifera in three replications illustrated that at the different concentrations of sodium azide and nitrous acid, the germination percentage and seedling survival were $100 \%$ in all the test plants. These results depicted that with the increase in concentration of mutagens there was no decrease or increase in germination percentage and survivorship of the studied species.

The closer view of the data collected on the seedling height illustrated that the potency of the mutagens at such varying concentrations for the two studied species induced a very distinct and obvious variations into the shoot length of the studied species.
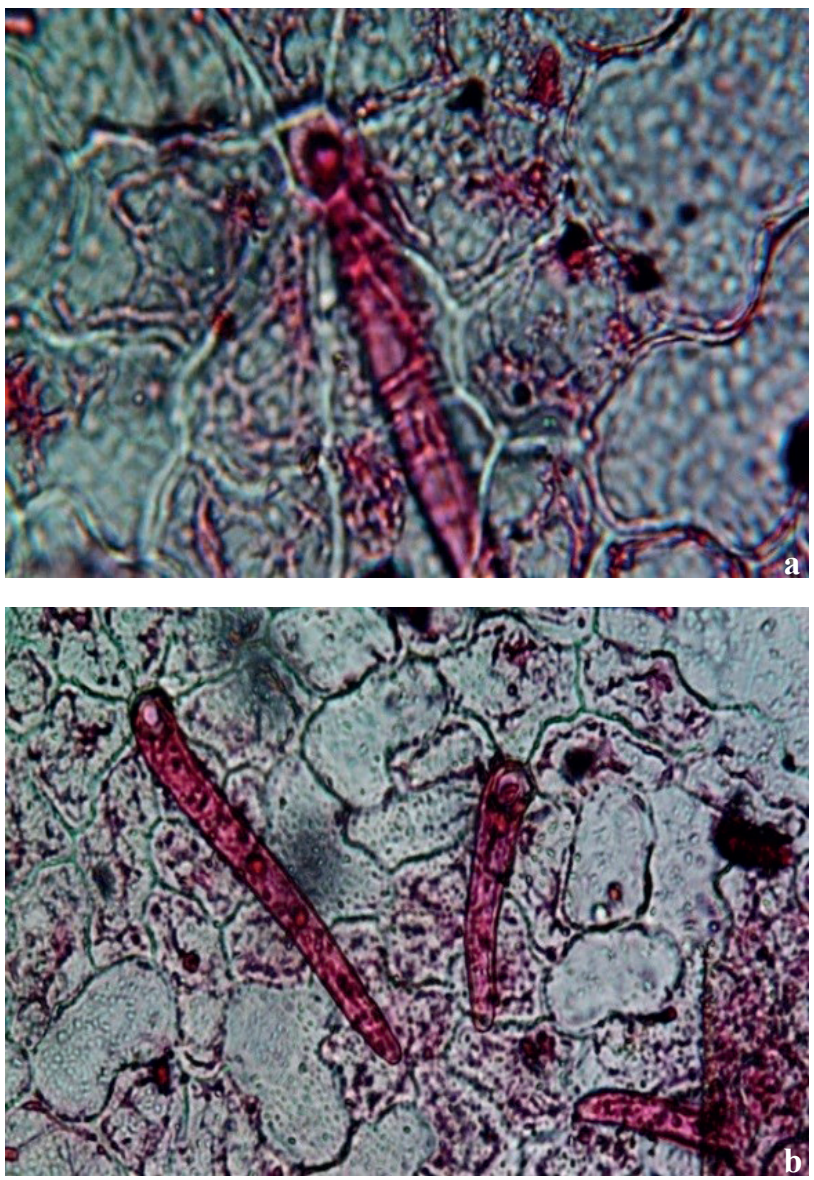

Figure 5. Unicellular trichomes on the Moringa oleifera leaf adaxial (a) and abaxial (b) surfaces. Magnification: $\times 600$.

Nitrous acid reduced the growth of $C$. lanatus and increases the growth in M. oleifera. This clearly shows that at the low of $1 \mathrm{mM}, 2 \mathrm{mM}$ and $4 \mathrm{mM}$ of nitrous acid is potent to affect the growth of $C$. lanatus and while on the other hand, sodium azide does not equal the growth of non-treated seedling but rather increases the growth except for the root length. This is contrary to the result of mutagenic effects of sodium azide on the growth and yield characteristics in wheat (Srivastava et al. 2011).

Stomata are present on both the leaf surfaces and/or on one surface of the leaf. When the stomata are present on both the sides of the leaf, then they are called amphistomatic as it is on watermelon and, if they are present on the lower side only as in M. oleifera leaves, then they are called hypostomatic (Metcalfe $\&$ Chalk 1988). The stomata cover nearly $1-12 \%$ of the leaf surface. The stomatal size in watermelon is small and varies due to the effect of the treatments. The value of the stomatal size on the adaxial surface of the control is $42.12 \mu \mathrm{m}$ and $19.59 \mu \mathrm{m}$ on the abaxial 


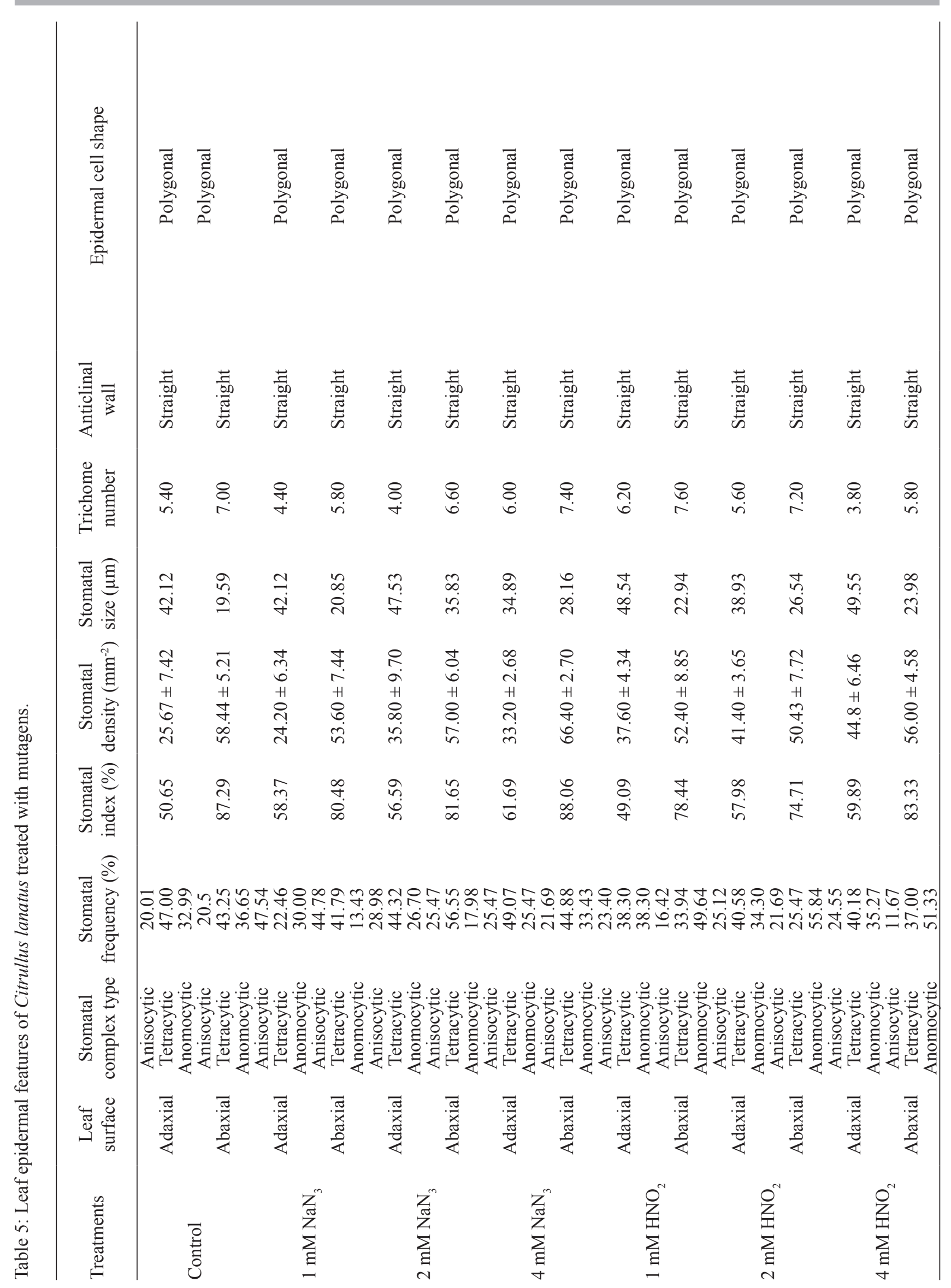




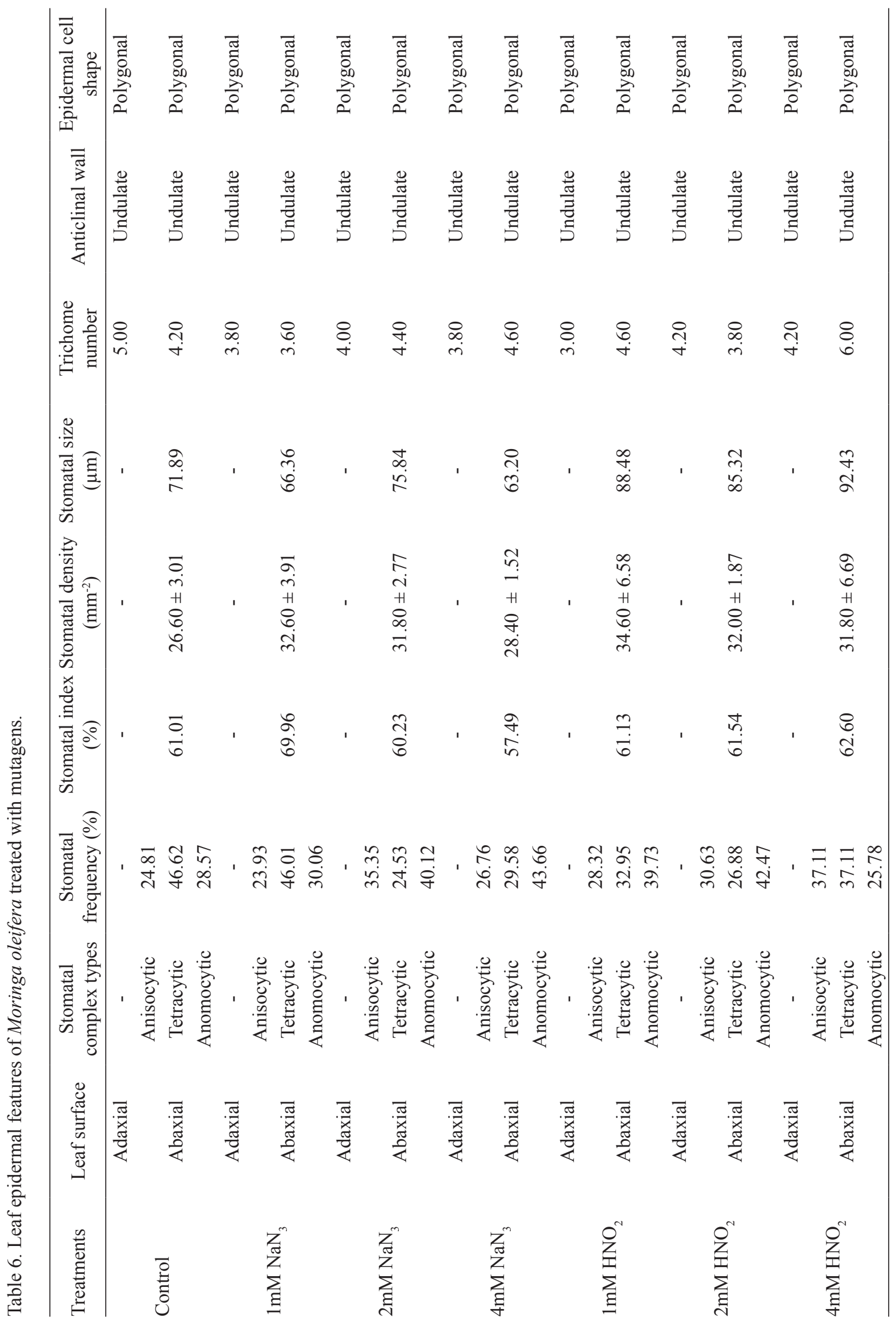



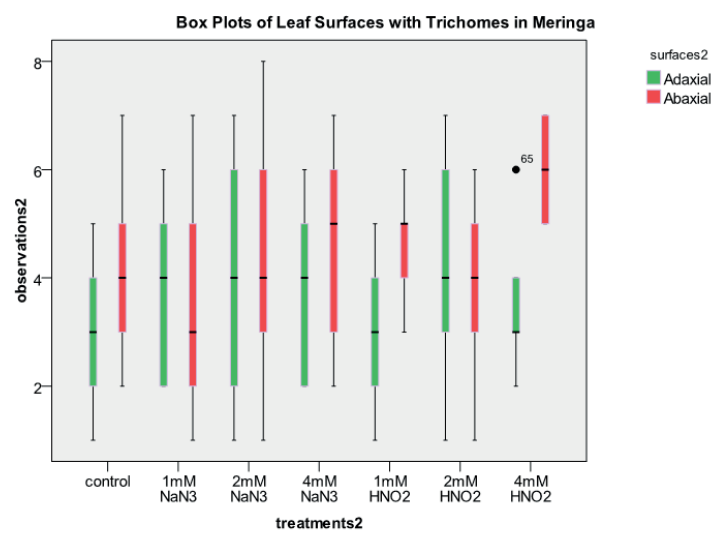

Figure 6: Trichome distribution on the leaf surfaces of Moringa oleifera.

surface. The treatments have the stomatal values on the adaxial surface ranging from a minimum value of $35.83 \mu \mathrm{m}$ to maximum value of $49.55 \mu \mathrm{m}$ due to the effect of the chemical mutagens. At $1 \mathrm{mM}$ $\mathrm{NaN}_{3}$, the stomatal size is the same with that of the control indicating that at such a low concentration, the $\mathrm{NaN}_{3}$ cannot induce any changes to the stomatal size, meanwhile at $1 \mathrm{mM} \mathrm{HNO}_{2}$ the stomatal size increased by $6.42 \mu \mathrm{m}$ on the adaxial and $3.35 \mu \mathrm{m}$ on the abaxial. The same observation was drawn at each other concentration level of the mutagens. Contrastingly, both $\mathrm{HNO}_{2}$ and $\mathrm{NaN}_{3}$ were potent enough to induce change to the stomatal size of the watermelon with $\mathrm{HNO}_{2}$ being the most potent on the adaxial and $\mathrm{NaN}_{3}$ potent on the abaxial surface. These findings correlated to the findings of Metcalfe \& Chalk (1988) that stomatal size is often correlated with stomatal density such that small stomatal give high density and large stomata give low density.

The mutagenic effects of the chemical mutagens successfully induced obvious change to the stomatal size. The value of the stomatal size of the adaxial surface for the control is $63.20 \mu \mathrm{m}$. This value is greater than that of the $2 \mathrm{mM} \mathrm{NaN}_{3}$ and $2 \mathrm{mM} \mathrm{HNO}_{2}$ but lesser than the rest of the stomatal size value. On the abaxial surface the stomatal size of the control is $56.98 \mu \mathrm{m}$ and this value is greater than that of $1 \mathrm{mM} \mathrm{NaN}_{3}$ but lesser to the rest of the values for the stomatal size at other concentrations. This correlated to the findings of Metcalfe and Chalk (1988) which concluded that stomatal size is often correlated with stomatal density such that small stomatal give high density and large ones give low density according to the values provided on tables 16,18 and 19 . The control value is also greater than that of the $1 \mathrm{mM}$ $\mathrm{NaN}_{3}$ and $4 \mathrm{mM} \mathrm{NaN}_{3}$ but lesser than others.

The increase in the stomatal size of the studied species caused as a result of the mutagenic treatment is advantageous to the physiology of food crop, trees or ornamental plants inhabiting the tropical zone or the temperate region. This is because the increase in the stomatal size will increase the transpiration rate and this will lead to the increase in the photosynthesis of the plant, thereby, promote and facilitate the plant growth at a very faster rate during the wet season and invariably increase the production of farm products. Meanwhile, if this increment in the stomatal size occurred in the dry season and if it is does not check, this may lead to the physiological disorder such as wilting. It however can be said that physiological process called transpiration is a necessary evil. This is because the increase in stomatal size will increase the size of the guard cells and since the photosynthetic organelle (chloroplast) is present in the mesophyll cells and guard cells as well, this will incessantly increase the chloroplast cells which contain larger amount of chlorophyll molecules on the leaf surfaces (Encarta 2009). This will efficiently contribute to the photosynthetic production of ATP, production of osmotically active sugars by photosynthetically carbon assimilation (Talbott \& Zeiger 1998) and the guard cells could also accumulate starch in the dark and hydrolyze it in the light and could also store starch, either from carbon assimilated in the guard cell chloroplasts or imported from the mesophyll of the leaf.

Trichomes and stomata are possible indicators of water economy in plant (Abdulrahaman \& Oladele 2011). Trichome increases the reflection of solar radiation, thereby reducing the internal temperature and thus reducing the water loss in the plants growing under arid condition. According to the value provided on table 15 for the occurrence of trichomes on the leaf surface of the $C$. lanatus, except for the $4 \mathrm{mM} \mathrm{HNO}_{2}$ on the adaxial surface, there was an increase in the trichomes number at any other concentration. This will help the plant to harvest the dew, reduce water loss and conserve water. There was no increase in the trichomes number on the adaxial surface of the leaf of $M$. oleifera whereas there was an obvious increase on the abaxial surface of the leaf.

The effect and prospect of sodium azide to induced favourable mutation into the morphology and anatomy of the test plants has been clearly shown to be of greater advantage since it increases the seedling height and several other anatomical features that promote the 
growth, seed production and yield of the test plants which is in contrast to the effect of the nitrous acid that is detrimental to the test plants; dwarfs the test plant, making them unable to withstand desication and as well impacted irregular leave formation to the test plants. Sodium azide is therefore recommended for effective usage by the farmer to improve the traits in plants and ultimately increase the possibility of isolating beneficial mutants for improvement of the economic crops such as the test plants.

In general, the increase in the stomatal density of the studied species caused as a result of the mutagenic treatment is also advantageous to the physiology of food crop, trees or ornamental plants inhabiting the tropical zone or temperate region. This is because the increase in the stomatal density will increase the transpiration rate and this will lead to increase in photosynthesis of the plant, thereby, promote and facilitate the plant growth at a very faster rate during the wet season and invariably increase the production of farm products. Meanwhile, if this increment in the stomatal density occurred in the dry season and if it is not checked, this may lead to the physiological disorder such as wilting. AbdulRahaman \& Oladele (2008) had earlier reported this occurrence where higher stomatal density and vice versa had effects on transpiration and humidification. Increase in stomatal density means increase in the number of the guard cells and since the photosynthetic organelle (chloroplast) is present on the mesophyll cells and guard cells as well, this will incessantly increase the chloroplast cells which contain larger amount of chlorophyll molecules on the leaf surfaces (Encarta 2009).

Trichomes are one of the epidermis appendages on plants and certain protist. They are ranging from unicellular, multicellular or glandular. Trichomes and stomata are possible indicators of water economy in plant (Abdulrahaman \& Oladele 2011). Trichome increases the reflection of solar radiation, thereby reducing the internal temperature and thus reducing the water loss in the plants growing under arid condition. The occurrence of trichomes on the leaf surface of the C. lanatus, except for the $4 \mathrm{mM} \mathrm{HNO}_{2}$ on the adaxial surface, there was an increase in the trichomes number at any other concentration. This will help the plant to harvest the dew, reduce water loss and conserve water.

The effect and prospect of sodium azide to induced favourable mutation into the morphology and anatomy of the test plant has been clearly shown to be of greater advantage since it increases the seedling height and several other anatomical features that promote the growth, seed production and yield of the plant. The same occurrences were observed in plants treated with the nitrous acid with lesser effects than the sodium azide. Sodium azide, and to some extent nitrous acid, is therefore recommended for effective use by the farmer to improve certain traits in plants and ultimately increasing the possibility of isolating beneficial mutants for improvement of the economic crops such as the test plants.

\section{Literature cited}

AbdulRahaman, A.A., Afolabi, A.A., Olayinka, B.U., Mustapha, O.T., Abdulkareem, K.A. \& Oladele, F.A. 2013. Effects of sodium azide and nitrous acid on the morphology and leaf Anatomy of Jatropha curcas L. (Euphorbiaceae). International Journal of Phytofuel and Allied Sciences 2: 30-41.

AbdulRahaman, A.A. \& Oladele, F.A. 2008. Global warming and stomatal complex types. Ethnobotanical Leaflets 12: 553-556.

Abdulrahaman, A.A. \& Oladele, F.A. 2011. Response of trichomes to water stress in two species of Jatropha. Insight Botany 1: 15-21.

Adamu, A.K. \& Aliyu, H. 2007. Morphological effects of sodium azide on tomato (Lycopersicon esculentum Mill). The Scientific World Journal 2: 9-12.

Ahloowalia, B.S. \& Maluszynski, M. 2001. Induced Mutation. A new paradigm in plant breeding. Euphytica 118: 167-173.

Al-Qurainy, F. 2009. Effects of sodium azide on growth and yield traits of Eruca sativa L. World Applied Sciences Journal 7: 220-226.

Bertagne-Sagnard, B.G. \& Chupeau, Y. 1996. Induced albino mutations as a tool for genetic analysis and cell biology in flax (Linum usitatssimum). Journal of Experiemental Botany 47: 189-194.

Burnotte, J. \& Verly, W.G. 1971. A kinetic approach to the mechanism of deoxyribonucleic acid cross-linking by $\mathrm{HNO}_{2}$. The Journal of Biological Chemistry146:5914-5918.

Dilcher, D.L. I 974. Approaches to the identification of angiosperm remain. Botanical Review 40: 1-45.

Encarta. 2009. Leaf. Redmond, W.A., Microsoft Corporation, 2008.

FAOSTAT. 2008. Crops. FAOSTAT. Food and Agriculture Organization of the United Nation (Database). Available in http://faostat.fao.org/site/567/default.aspx\#ancor (access in 29-II-2013).

Franco, C. 1939. Relation between chromosome number and stomata in Coffea. Botanic Gazette 100: 817-818.

Grant, W.F. \& Salamone, M.F. 1994. Comparative mutagenecity of chemicals selected for test in the international program on chemical safety collaborative study on plant systems for the detection of environmental mutagens. Mutation Research 310: 187-209. 
Gruszka, D., Szarejko, I. \& Maluszynski, M. 2012. Sodium Azide as Mutagen. In: Plant Mutation Breeding and Biotechnology. CABI International, Willingford, UK., pp. 159-166.

Leone, A., Spada, A., Battezzati, A., Schiraldi, A., Aristil, J. \& Bertoli, S. 2015. Cultivation, genetic, ethnopharmacology, phytochemistry and pharmacology of Moringa oleifera leaves: an overview. International Journal of Molecular Science 16: 12791-12835.

Mahandjiev, A., Kosturkova, G. \& Mihov, M. 2001. Enrichment of Pisum sativum gene resources through combined use of physical and chemical mutagens. Israel Journal of Plant Sciences 49: 279-284.

Metcalfe, C.R. \& Chalk, L. 1988. Anatomy of Dicotyledons (2nd. edn). Oxford University Press, Oxford, pp. 97-177.

Miller, J.H. 1972. Experiments in Molecular Genetics. Cold Spring Harbor Laboratory, Cold Spring Harbor, NY, pp. 137-138.

Mishra, L., Vernekar, M. \& Harmalker, M. 2014. Effect of $\mathrm{UV}$ and nitrous acid treatment on production of xylanase enzyme by Achinetobacter sp. International Journal of Current Microbiology and Applied Sciences 3: 45-53.
Obiremi, E.O. \& Oladele, F.A. 2001. Water-conserving stomatal systems in selected Citrus species. South Africa Journal of Botany 57: 258-260.

Parotta, J.A. 1993. Moringa oleifera Lam. Reseda, horseradish tree. Moringaceae. Horseradish tree family. (PDF). USDA Forest Service, International Institute of Tropical Forestry.

Raicu, P. \& Mixich, F. 1992. Cytogenetic effects of sodium azide encapsulated in liposomes on heteroploides cell cultures. Mutation Research 283: 215-219.

Srivastava, P., Marker, S., Pandey, P. \& Tiwari, D.K. 2011. Mutagenic effect of sodium azide on the growth and yield characteristics in wheat. Asian Journal of Plant Sciences 10: 190-201.

Van, R.W., Den-Bulk, H.J., Loffer, L.W.H. \& Koornneef, M. 1990. Somaclonal variation in tomato: effect of explants source and a comparison with chemical mutagenesis. Theoretical Applied Genetics 80: 817-825.

Wen, J.G. \& Liang, H.G. 1995. Effect of $\mathrm{KCN}$ and $\mathrm{NaN}_{3}$ pretreatment on the cyanide resistant respiration in tobacco callus. Acta Botanica Sinica 37: 711-717. 